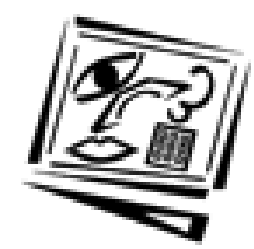

\title{
Designing real life cases to support authentic design activities
}

\author{
Sue Bennett, Barry Harper and John Hedberg \\ University of Wollongong
}

\begin{abstract}
Teachers in a range of disciplines are interested in engaging their students in authentic activities that reflect the experiences of real world practitioners. Adopting this approach requires the design and implementation of learning environments that incorporate and support such activities. This paper describes two real life cases developed as support materials for learners undertaking a major multimedia design project. Their implementation in a graduate education subject forms the basis of a wider study investigating learners' interpretations and use of case materials.
\end{abstract}

\section{Introduction}

Many teachers recognise the value in involving their students in tasks that reflect the way knowledge and skills are used in practice. The challenge they face is to incorporate these authentic activities and the realistic contexts needed to support them into the learning experiences they design for their students. One popular method for illustrating the complexities of real life is with cases which present detailed accounts of situations through the actions of key characters, the issues that arise and the outcomes that eventuate. As part of a study into how learners interpret these rich sources of information, two cases documenting real life design projects were created to prepare students embarking on the development of their own multimedia package. This paper describes the theoretical framework, design decisions and the implementation of the cases in a graduate subject which was the focus of the investigation.

\section{Theoretical framework}

\section{Authentic activities}

Many theorists argue the importance of providing students with authentic experiences - experiences that reflect real world ways of knowing and doing. It is thought that such experiences allow learners to transfer 
knowledge from formal education to practice, and so provide opportunities for meaningful learning.

These ideas are based on recent re-conceptions of learning which suggest that (Grabinger, 1996, p.667):

1. "People transfer learning with difficulty, needing both context and content learning."

2. "Skills and knowledge are best acquired within realistic contexts."

3. "Assessment must take more realistic and holistic forms."

In designing learning environments to support these authentic activities there must be an alignment between the context in which learning is presented in the formal setting and the real life setting in which that knowledge will be called upon. But what is meant by authenticity and how can these kinds of experiences be designed and supported?

Some researchers conceive of a generic kind of authenticity. Such activities achieve authenticity because they reflect the nature of real problems as being complex, ill-structured, collaborative, containing multiple perspectives and offering multiple paths and solutions (Young, 1993; Squires, 1999). Jonassen (1999) suggests that an authentic activity may simply be one that is personally meaningful to the learner - that is engaging and relevant in a way that assists them in their own meaning-making.

Other researchers argue that emphasis should be placed on engaging students in cognitive processes that reflect the real world counterpart (Anderson et. al., 1996). This would involve learners in the same types of cognitive challenges as are present in the work environment, but not necessarily in exactly the same tasks an expert practitioner would perform (Savery \& Duffy, 1996).

Honebein, Duffy and Fishman (1993) argue that an activity is not inherently authentic, but authentic in relation to some other activity. The level and nature of authenticity presented to learners will depend upon many factors. Some situations may require a high level of sensory fidelity in their representation so that practical skills may be developed. Other learning situations may focus more upon developing or applying conceptual knowledge or skills, such as critical thinking or problem solving. In others social interaction and negotiation may be crucial.

\section{Case based learning}

There are a variety of reasons espoused for adopting a case based approach to learning. A prominent argument is that case based learning involves 
complex, authentic situations in which the learner (usually a novice) must learn to think like a practitioner (an expert). This reflects a view that learning is a process of moving towards greater expertise.

Cases offer a means to contextualise learning in a way that connects content and action. Schank and Cleary (1995) characterise case based learning as a natural extension of our ability to learn from previous experience. Experts are people with a store of previous cases upon which they draw when confronted by a new situation. Jonassen (1999) argues that the inclusion of cases in a constructivist learning environment provides learners with access to experiences that they have not previously encountered. Furthermore a case based approach which combines engagement with meaningful real world tasks and expert coaching can provide deeper insights into processes and practices (Jonassen, 1993).

Riesback (1996) describes case based reasoning as requiring learners to compare a new situation to previous experiences, by looking for matching characteristics and then adapting old solutions to create a new one. In order to successfully retrieve previous cases, learners must label (or index) them appropriately at the time of learning - the goal of learning being to transfer knowledge to a new situation.

Using cognitive flexibility theory as their basis, Spiro and Jehng (1990) argue that multiple representations, such as those offered by case based instruction, best support learning in complex, ill-structured knowledge domains. Their approach attempts to retain the complexities and contradictions inherent in realistic situations.

The use of cases for learning is not new. Case based instruction has a firmly established tradition in professional disciplines such as business and law, most notably at Harvard University (Sykes \& Bird, 1992). Recently cases have found application in other disciplines, such as teacher education, educational psychology and instructional design (Ertmer \& Russell, 1995; Kinzie et. al., 1998).

Although case based learning has developed a variety of interpretations and applications, the approach is most broadly defined as requiring "students to actively participate in real or hypothetical problem situations, reflecting the kind of experiences naturally encountered in the discipline under study" (Ertmer \& Russell, 1995, p.24). Different conceptions of teaching and learning will determine the nature of the cases developed and the ways in which learners interact with the materials (Merseth, 1991). Most authors discuss two aspects of the case method: a) the case narrative or description and; b) the implementation of the case (or cases) in the learning environment. 
Cases may act as examples or illustrations, present new knowledge or describe a problem situation. Cases may be paradigmatic, exemplary or idiosyncratic. The essence of a case is the description of the context, including the physical, social and organisational aspects (Jonassen, 1999). Materials may consist of one detailed case requiring sustained engagement, possibly from multiple perspectives, or feature short vignettes on a variety of topics. As noted by Sykes and Bird (1992), little is known of the effectiveness of these alternatives and their suitability is likely to depend upon such factors as the availability of background material and the desired learning outcomes.

The representation of the case based learning materials must also be considered. While text is a popular traditional medium, the Cognition and Technology Group at Vanderbilt (1992) prefer to use high quality video and computer based formats which offer increased scope for sensory fidelity (see also McClellan, 1991). Supporting resources may include written documentation (including letters, reports, memos, articles), graphics, audio, video or animation.

The most common approach to implementation of cases incorporates study questions as a focus for individual reflection, small group deliberations and whole class discussion (Ertmer and Russell, 1995). Variations on this approach include: participation in the case as a simulation or field experience (Sykes and Bird, 1992); inclusion of cases as support for decision making (Edelson, 1993) and; student preparation of their own cases (Benham, 1996).

Support for learners in the form of scaffolding and modelling may also be a feature of a case based approach. Spiro and Jehng (1990) advocate the inclusion of commentaries which provide learners with expert guidance by explaining how cases relate to themes and how themes are related to each other. Jonassen (1996) describes a case based learning environment that aims to bridge the gap between advanced biomedical knowledge and its application to real world clinical diagnosis, with scaffolding in the form of calculation tools provided at major decision points, prompting learners to investigate relationships between variables. Miller and Kantrov (1998) emphasise the need for case analysis to take learners beyond the immediate scope of the case context to address larger issues and extract generalisations.

It is important to make a distinction between approaches which are predominantly case or problem based. Problem based learning shares many of the same attributes as the case approach in that it seeks to engage learners in authentic activities within realistic situations. Ogden (1984) makes the useful distinction that case based learning is the study of past 
solutions whereas problem based learning involves developing a 'new' solution. Cases are of value in providing multiple perspectives and examples, particularly relevant for the kind of case to case reasoning required in a legal system reliant on precedents. Problem based approaches often use a case as the starting point only. For example, medical students working in small groups are presented with a problem situation constructed from actual patient records and using the process of research and clinical reasoning arrive at a diagnosis (Williams, 1992).

The literature on case based learning is dominated by theoretical arguments for its instructional effectiveness and descriptions of the design and application of a case based approach. There is however little research reporting on the nature of the case based learning experience - a shortcoming noted by many authors including McKeachie (1994) and Ertmer et. al. (1996). Specific studies have explored some aspects of case based learning, such as self regulation and problem solving behaviour, however these do not yet form a connected or comprehensive body of knowledge. In particular little is known of how learners make sense of the rich contextual information presented in a case and use that in other situations.

\section{The design of a case based learning environment}

\section{The setting}

The study was conducted with two groups enrolled in Interactive Multimedia Design, an advanced level subject in the Master of Education in IT program at the University of Wollongong. Students in the subject form small project teams and work with a real client to develop an interactive multimedia package which will address a specific educational need. The nature of the task requires learners to draw on conceptual knowledge and production skills developed in previous subjects, to work within a team of people with diverse interests and backgrounds, and to manage the relationship with a client who might have different expectations of the process and outcomes. These are also aspects of a real world multimedia design project, and through this activity learners encounter situations similar to those a professional designer would experience.

Like any other learning activity which aims to be authentic, there are limitations that need to be recognised. Although this is a team project, the other members of the development team are also students. This means that the relationships and hierarchy do not reflect those that would be found in a real world design team, with implications for the authority of the project manager in the student group. Also most of the team members will have rudimentary production skills rather than be experienced graphic 
designers, media production experts or programmers. This may impact on how team works together and manages their own and the client's expectations of the final product.

\section{Design of the subject}

There is arguably no such thing as a typical instructional design project. Each is influenced by a variety of factors including the educational philosophy of the teacher/designer, characteristics of the students, the institutional setting and the availability of human and financial resources, all of which must be assessed and reassessed throughout a project.

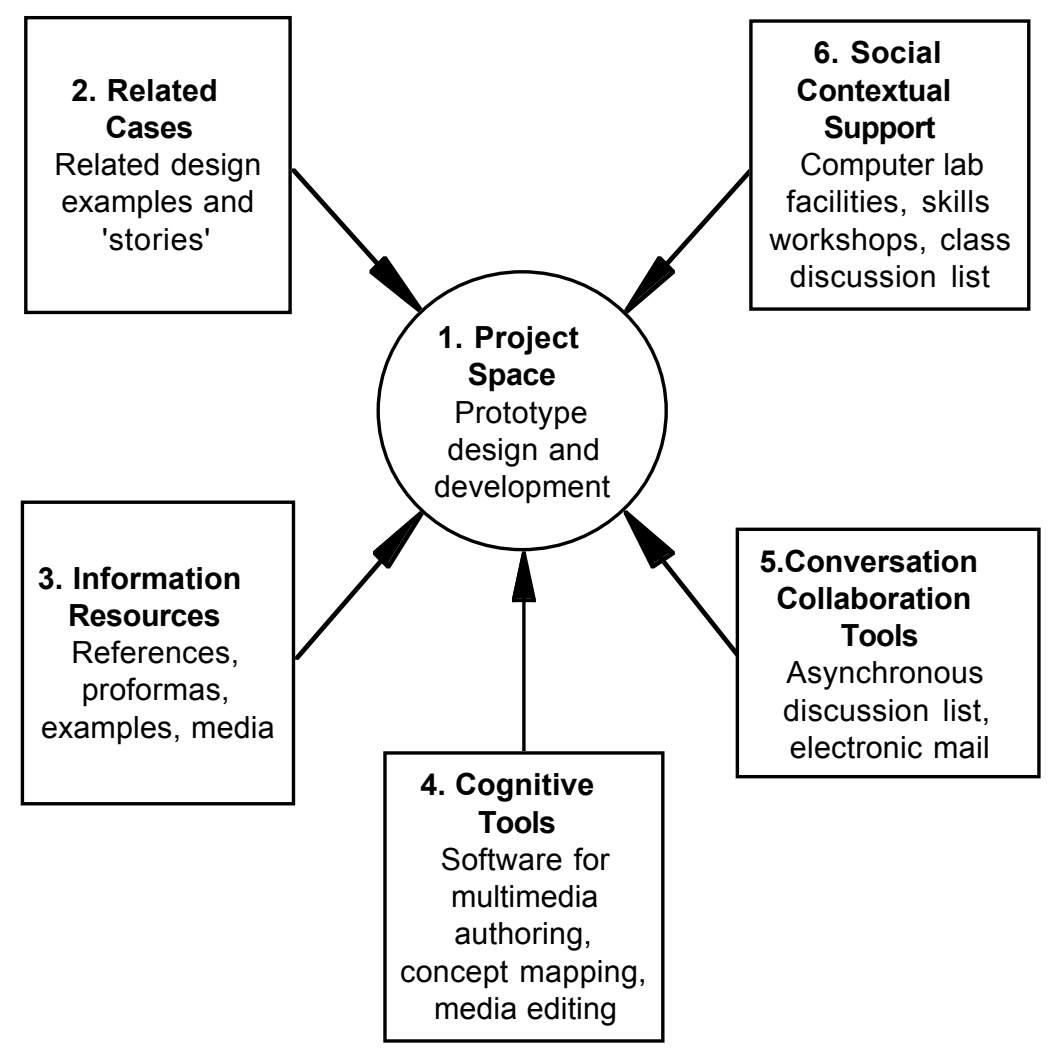

Figure 1: Jonassen's model for a constructivist learning environment

Goel and Pirolli (1988) argue that design problems by their very nature are not amenable to rule based solutions. The ill-structured nature of instructional design problems means that not only are there multiple paths towards a 'solution', but that there are multiple interpretations and 
solutions as well. Expert designers address these complex, multifaceted problems by drawing on their knowledge of theory and research and their previous professional experience.

Jonassen's (1999) model for a constructivist learning environment (CLE) provides a framework for supporting learners as they work on their own design problems. Cases present solutions to past problems that may compensate for learners' lack of experience and may help learners develop an understanding of concepts and strategies useful in similar situations. This model has been used as a framework for redesigning the subject, as described in Figure 1.

1. Project space

The project space is the focus of the learning environment and in this subject comprises the design 'problem' for which learners develop a multimedia solution. Students work in small project teams and liase with a real client. A number of clients are available for learners to chose from, or they may find their own. The design problems tend to be illstructured and complex and engage learners in the kind of thinking required by practitioners in the design and development of a project.

2. Related cases

Cases provide the main instructional support and analysis activities focus on developing the learner's understanding of instructional design through individual reflection and group discussion. The activities incorporate two facets of case based learning suggested in the literature - 1) learning from experts, and 2) developing ideas through personal reflection and social interaction. The two cases developed for this subject provides insights into the experiences of the designers that enhance learners' understanding of the development process.

3. Information resources

Information resources include references to relevant sources of information including readings and Web sites, proforma documents usable for guiding the development of design statements, examples and descriptions of other projects, and useful media resources.

4. Cognitive tools

Students use multimedia authoring software to explore and test their design ideas on screen, leading to a prototype version of their multimedia package. Other software tools are made available to assist learners with problem representation, concept mapping, information gathering and organisation, storyboarding and media design.

5. Conversation and collaboration tools Asynchronous communication tools, such as electronic mail and discussion lists, are used to support interpersonal, small group and 
whole class interaction. An array of other tools are available to meet the individual communication needs of the project teams.

6. Social and contextual support

Social and contextual support is provided through a class discussion forum for general communication, access to the computer laboratory facilities and other meeting spaces, and the scheduling of face to face meetings and optional skills development workshops. The role of the instructor as facilitator and mentor is an essential component of this environment.

\section{Design of the cases}

Ertmer and Russell (1995) suggest that instructional design students need to develop skills in problem solving, critical thinking and reasoned judgement needed to work with complex, multi-faceted design problems. Table 1 below outlines the design principles that underpin the development of the cases in relation to the desired outcomes for this subject and the team design activities.

The instructional design cases prepared for this study illustrate the nature of design problems as ill-structured and ill-defined. The two cases are real life examples, tracing the development of Exploring the Nardoo and StageStruck by the Interactive Multimedia Learning Laboratory in the Faculty of Education at the University of Wollongong. The cases present the approach of the project designers to interpreting the needs of the client and target learners, developing appropriate instructional solutions, representing their design ideas and implementing these in the product. The cases are not presented as exemplars, but instead aim to convey the multiple issues which arose and to illustrate the ambiguities and contingencies that are part of the design and development process.

The case materials themselves depart from the traditional narrative form in which the case author summarises the events for the learner. As the intention is to provide a rich information source that learners can explore and make sense of themselves, materials are maintained in their 'rawest' form. In doing so it is possible to maintain a level of detail, complexity and ambiguity which would be more difficult to achieve in a concise format.

Constructed as a series of Web pages linked from the main subject site, the various components are linked from an introductory page which provides a brief overview of the project and a timeline of major events. These were developed from archival records of the projects including meeting notes, email communication and diary entries. They are the only 'pre-packaged' materials included and from here learners can follow links to a range of other resources. 
Table 1: Desired outcomes against case analysis and project tasks

\begin{tabular}{|l|l|l|}
\hline $\begin{array}{l}\text { Instructional design } \\
\text { students need to develop the } \\
\text { knowledge and skills to: }\end{array}$ & $\begin{array}{l}\text { Case materials and activities } \\
\text { aim to develop these skills by } \\
\text { engaging learners with } \\
\text { realistic, detailed design } \\
\text { cases which: }\end{array}$ & $\begin{array}{l}\text { The team design activities } \\
\text { aim to develop these skills by } \\
\text { engaging learners in a } \\
\text { project which requires them } \\
\text { to: }\end{array}$ \\
\hline $\begin{array}{l}\text { make sense of a complex } \\
\text { design problem by } \\
\text { identifying and analysing } \\
\text { the critical issues in a } \\
\text { situation }\end{array}$ & $\begin{array}{l}\text { contain multiple issues } \\
\text { and perspectives }\end{array}$ & $\begin{array}{l}\text { describe and assess the } \\
\text { features of a particular } \\
\text { learning problem }\end{array}$ \\
\hline $\begin{array}{l}\text { consider multiple } \\
\text { possibilities for design } \\
\text { solutions by applying } \\
\text { knowledge of } \\
\text { instructional strategies }\end{array}$ & $\begin{array}{l}\text { illustrate how designers } \\
\text { generate their initial ideas } \\
\text { from an understanding of } \\
\text { instructional strategies }\end{array}$ & $\begin{array}{l}\text { consider how different } \\
\text { strategies might be } \\
\text { applied to a particular } \\
\text { learning situation }\end{array}$ \\
\hline $\begin{array}{l}\text { select the most } \\
\text { appropriate solution by } \\
\text { considering possible } \\
\text { designs in light of } \\
\text { situational factors }\end{array}$ & $\begin{array}{l}\text { illustrate how designers } \\
\text { determine which methods } \\
\text { are most suitable in a } \\
\text { particular situation given } \\
\text { a range of contextual } \\
\text { factors }\end{array}$ & $\begin{array}{l}\text { determine which design } \\
\text { solution would be most } \\
\text { appropriate in a } \\
\text { particular situation }\end{array}$ \\
\hline $\begin{array}{l}\text { communicate design } \\
\text { decisions to others and } \\
\text { negotiate as necessary }\end{array}$ & $\begin{array}{l}\text { include details of } \\
\text { communication between } \\
\text { designers and others }\end{array}$ & $\begin{array}{l}\text { work with a real client to } \\
\text { whom they must explain } \\
\text { and justify their design } \\
\text { decisions }\end{array}$ \\
\hline $\begin{array}{l}\text { document and / or } \\
\text { prototype a design } \\
\text { solution }\end{array}$ & $\begin{array}{l}\text { include relevant } \\
\text { documents and files as } \\
\text { part of the case materials }\end{array}$ & $\begin{array}{l}\text { prepare a description of } \\
\text { their design within a } \\
\text { design statement template }\end{array}$ \\
\hline $\begin{array}{l}\text { evaluate a design solution } \\
\text { in terms of the initial } \\
\text { problem }\end{array}$ & $\begin{array}{l}\text { include the designer's } \\
\text { reflections on the overall } \\
\text { process and solution }\end{array}$ & $\begin{array}{l}\text { evaluate their design } \\
\text { solution by reflecting on } \\
\text { their project experiences } \\
\text { and their original } \\
\text { intentions }\end{array}$ \\
\hline
\end{tabular}

These include accounts from the key project designers which, apart from minor editing to improve readability, are included as direct transcripts of interviews conducted with the researcher. This allows learners to read the conversation in its original context and in the designer's own words. Students can also examine original design documents, including versions of the project design statements, storyboards, concept maps and early prototypes. Also included are reviews of the final products and papers written about subsequent research projects. Copies of the CD-ROM products are also provided to learners so that they can examine them in conjunction with the case accounts. 


\section{Implementation}

The aim of the cases was to provide learners who were beginning work on their own team projects with access to accounts of other projects which might have relevance to their own. To focus their study of the cases, they were given a series of analysis questions for which they provided individual responses. These questions asked them to describe the design process and key events, relate the experiences of the case designers to concepts from the literature and/or their own experiences, examine a particular design feature, and identify the major management issues.

At the next class meeting a discussion in their project teams focussed on how the design and management issues highlighted in the case might be relevant to their own projects. These issues were then shared in a whole class discussion. This series of activities was designed to allow the learner to first develop their own ideas about the cases and then to share them with the other members of their team and later with the whole class group. The intention was also to take them from specific discussion of the cases to the broader issues and lead into their own project experience (as suggested by Miller and Kantrov, 1998).

Towards the completion of their group projects learners were also required to respond individually to a series of reflective questions and then submit their own reflective case, developed collaboratively by the project team. The aim of this task was to draw them out of the often all-consuming project development tasks and ask them to again examine the main design and management issues, now in terms of their own project experience.

Data collected throughout the session, in the form of student work, discussion list transcripts and interviews with students and the instructor, are currently being analysed. It is anticipated that investigation of individual responses and the patterns and themes which emerge will provide insights into the ways learners examine and interpret the cases and use their understanding of them to inform their own project work.

\section{Conclusion}

An examination of the literature advocating the use of authentic activities suggests that cases may be useful in helping learners develop an understanding of the complexities of real life situations. Two real life cases developed to support learners undertaking a major design project provide a rich source of information featuring personal accounts and original documents. It is intended that learners will be prompted by the case analysis questions to explore the multiple perspectives and issues within the cases to develop their own view of the development process, and in 
discussion with others in their team and class explore the wider issues. This process of analysis, experience and reflection could also be applied to other learning situations in which learners with varying backgrounds and skills could benefit from the opportunity to examine a related case before they embark on their experience.

\section{References}

Anderson, J. R, Reder, L. M. \& Simon, H. A. (1996). Situated learning and education. Educational Researcher, May, 4-11.

Benham, M. (1996). The practitioner-scholars' view of school change: A case-based approach to teaching and learning. Teaching and Teacher Education, 12(2), 119-135.

Cognition and Technology Group at Vanderbilt (1997). The Jasper Project. Mahwah, NJ: Lawrence Erlbaum Associates.

Edelson, D. C. (1993). Socrates, Aesops and the computer: Questioning and storytelling with multimedia. Journal of Educational Multimedia and Hypermedia. 2(4), 393-404.

Ertmer, P. A. \& Russell, J. D. (1995). Using case studies to enhance instructional design education. Educational Technology, 35 (4), 23-31.

Ertmer, P. A, Newby, T. J. \& MacDougall, M. (1996). Students' responses and approaches to case-based instruction: The role of reflective self-regulation. American Educational Research Journal, 33(3), 719-52.

Goel, V. \& Pirolli, P. (1988). Motivating the notion of generic design with information processing theory: The design problem space. School of Education, California University, Berkeley.

Grabinger, S. (1996). Rich environments for active learning. In D. H. Jonassen (Ed), Handbook of Research for Educational Communications and Technology. New York: Macmillan Library Reference.

Honebein, P. C., Duffy, T. M. and Fishman, B. J. (1993). Constructivism and the design of learning environments: Context and authentic activities for learning. In T. M. Duffy, J. Lowyck and D. H. Jonassen (Eds), Designing Environments for Constructive Learning (pp. 87-108). Berlin: Springer-Verlag.

Jonassen, D., Mayes, T. \& McAleese, A. (1993). A manifesto for a constructivist approach to uses of technology in higher education. In T. M. Duffy, J. Lowyck and D. H. Jonassen (Eds), Designing Environments for Constructive Learning (pp. 231-247). Berlin: Springer-Verlag.

Jonassen, D. H. (1996). Scaffolding diagnostic reasoning in case-based learning environments. Journal of Computing in Higher Education, 8(1), 48-68.

Jonassen, D. (1999). Designing constructivist learning environments. In C. M. Reigeluth (Ed), Instructional Theories and Models (2nd ed, pp. 215-239). Mahwah, NJ: Lawrence Erlbaum Associates.

Kinzie, M. B., Hrabe, M. E. \& Larsen, V. A. (1998). An instructional design case event: Exploring issues in professional practice. Educational Technology Research and Development, 46(1), 53-71. 
McLellan, H. (1991). Virtual environments and situated learning. Multimedia Review, 2(3), 30-37.

McKeachie, W. J. (1994). Teaching Tips. Lexington, MA: DC Heath and Co.

Merseth, K. K. (1991). The early history of case-based instruction: Insights for teacher education today. Journal of Teacher Education, 42(4), 243-9.

Miller, B. \& Kantrov I. (1998) A Guide to Facilitating Cases in Education. Portsmouth, NH: Heinemann.

Ogden, G. L. (1984). The problem method in legal education. Journal of Legal Education, 34, 654-673.

Riesback, C. (1996). Case-based teaching and constructivism: Carpenters and tools. In B. G. Wilson (Ed), Constructivist Learning Environments: Case Studies in Instructional Design (pp. 49-61). Englewood Cliffs, NJ: Educational Technology Publications.

Savery, J. R. \& Duffy, T. M. (1996). Problem based learning: An instructional model and its constructivist framework. In B. G. Wilson (Ed), Designing Constructivist Learning Environments. Englewood Cliffs, NJ: Educational Technology Publications.

Schank, R. C. \& Cleary, R. (1995). Engines for Education. Hillsdale, NJ: Erlbaum.

Spiro, R. \& Jehng, J-C. (1990). Cognitive flexibility and hypertext: Theory and technology for the nonlinear and multidimensional transversal of complex subject matter. In D. Nix \& R. Spiro (Eds), Cognition, Education, Multimedia: Exploring Ideas in High Technology. Lawrence Erlbaum, New Jersey.

Squires, D. (1999). Educational software and learning: Subversive use and volatile design. Educational Technology, 39(3), 48-54.

Sykes, G \& Bird, T. (1992). Teacher education and the case idea. In G. Grant (Ed.), Review of Research in Education, 18, 457-521. Washington, DC: American Educational Research Association.

Williams, S. M. (1992). Putting Case-based Instruction into Context: Examples from Legal and Medical Education. The Journal of the Learning Sciences, 2(4), 367-427.

Young, M. F. (1993). Instructional design for situated learning. Educational Technology Research and Development, 41(1), 43-85.

Sue Bennett, Barry Harper and John Hedberg, Faculty of Education, University of Wollongong, Northfields Avenue, Wollongong NSW 2522 Contact person: sue_bennett@uow.edu.au

An earlier version of this article was published under:

Bennett, S., Harper, B. \& Hedberg, J. (2001). Designing real-life cases to support authentic design activities. In G. Kennedy, M. Keppell, C. McNaught \& T. Petrovic (Eds), Meeting at the Crossroads. Proceedings of the 18th Annual Conference of the Australasian Society for Computers in Learning in Tertiary Education. (pp. 73-81). Melbourne: Biomedical Multimedia Unit, The University of Melbourne.

http:/ / www.medfac.unimelb.edu.au/Ascilite2001/pubs/pdf/papers/bennetts.pdf 